\title{
Translation Norms in Gabriel García Márquez's Cien años de soledad Translations into English, German, French, Portuguese, and Russian
}

\author{
Normas de traducción en las versiones inglesa, \\ alemana, francesa, portuguesa y rusa de Cien años \\ de soledad de Gabriel García Márquez
}

Sergio Bolaños Cuéllar 1

\section{Abstract}

In this paper I have attempted to review the general translation norms that were applied in the translations of Cien años de soledad into English, German, French, Portuguese, and Russian. First I have discussed the concept of norms from a socio-cultural perspective in order to propose a definition of translation norms that could be used as a guiding concept in the analysis of the different translated texts. The discussion takes place within the framework of modern empirical Translation Studies that is based on the actual textual comparison of original and translations. Finally, some conclusions are drawn accordingly.

Key Words:

Translation norms, translation studies, domesticating, foreignizing, adaptation.

Resumen

En este artículo propongo revisar las normas generales de traducción que se emplearon en las traducciones inglesa, alemana, francesa, portuguesa y rusa de Cien años de soledad. En primer lugar, discuto la noción de normas desde un enfoque socio-cultural con el fin de proponer una definición de normas de traducción que pueda servir de concepto central en el análisis de las diversas traducciones. La discusión se lleva a cabo en el marco de los Estudios de la Traducción Modernos, con carácter empírico, que se basan en la comparación textual del original y las traducciones. Por último, se presentan las conclusiones respectivas.

Palabras clave:

Normas de traducción, estudios de la traducción, domesticación, extranjerización, adaptación.

1 Doctor en Lingüística (Universidad de Hamburgo). Profesor Asociado y actualmente Vicedecano Académico de la Facultad de Ciencias Humanas de la Universidad Nacional de Colombia. Director del grupo de investigación Comunicación, Bilingüismo y Traducción. sbolanosc@unal.edu.co 


\section{Introduction}

'Translation norms' is a useful concept in modern Translation Studies, for it helps us to understand the reason why a text has been translated properly or if some dramatic changes have occurred in the process so that the translated text can be best labelled as 'adaptation,' 'summary', 'parody', or any other similar text transformation. Before dealing with the topic of translation norms stricto sensu, it is important to clarify first the meaning of norms from a wider, socio-cultural perspective.

Members of a community acquire or learn the norms which are valid in their environment during their process of socialization (Hermans, 2000:12). If norms are broken it is likely that social sanctions take place ${ }^{2}$. Not all norms have the same binding force and

"The institutions or agents who exercise normative control tend to occupy positions of power and dominance in the particular field where the norms apply, or indeed in higher-level fields, i.e. fields closer to the overreaching center of power in the community" (ibid:13).

An additional characteristic of norms is that they are historically determined, i.e. they change as the individuals' and communities' predominant values change, a process which indeed can take a long time to complete. It is also important to bear in mind that several diverse norms may be competing at a given period of time; they can and actually do co-occur. Thus, we can say that the main characteristics of socio-cultural norms in general (being dictated by the powerful instances in the community, displaying a prescriptive force of what is 'correct' or 'proper' and therefore 'should' be done, co-occurring and changing as the community changes its values) also apply to linguistic and translation norms as they are part of the complex network of socio-cultural norms (Bolaños, 2008:154).

2 In toury's words: "norms are acquired by the individual during his/ her socialization and always imply sanctions - actual or potential, negative as well as positive". (1995, p.55).
Thus, it is my view that translation norms are made up of linguistic norms and socio-cultural canons. Linguistic norms, in turn, comprise systemic and textual typological norms ( $c f$. infra). Socio-cultural canons contain aesthetic-literary, religious, ideological as well as target language translation-related expected values: 'a translation should be faithful to the original', 'avoid the introduction of new literary genres', 'domesticate as much as possible', fereignize as much as possible', 'embellish as much as possible', 'avoid profanity at all costs', 'respect the original's content and form', 'adapt partially', etc. (ibid. 157).

Between linguistic norms and socio-cultural canons there appears to exist a relationship of dependence: the realization of linguistic (systemic and textual, $c f$. infra) means in the translated text depends on the socio-cultural canons which are perceived as valid by the translator in order to fulfil the commissioner's or initiator's communicative purpose at any given time.

Translation norms then should be understood as patterns for translation behaviour, which are established by diverse powerful instances in a socio-historical context of the Target Language (TL) community, change constantly as the community's values do, and are enforced linguistically by telling translators how to produce texts which are not only systemically correct (what is grammatically permitted in a given language), and text typologically appropriate (according to existing text types, modifying and/or introducing new text types), but above all translationally appropriate (according to valid conceptions about what the different translation text types should be: faithful to the original's form and content, to its form, to its content, to its overall 'motive'; overall domesticating, overall foreignizing, domesticating and foreignizing; adapting, summarizing, paraphrasing, etc.), (ibíd, p. 159).

This conception of translation norms would help to explain the fact that diverse and mutually exclusive translation norms have prevailed over the history of translation. For instance, as Robinson (2000, p.15) claims, "For ancient Rome, translation was strict, slavish literalism; any liberties the rewriter might be 
inclined to take with the source text were by definition beyond the limits of translation." Talking about the age of the so-called belles infideles, especially in France during the $17^{\text {th }}$ century, Albrecht (1998, p.76) considers that "domesticating translation as a cultural norm prevailed, a trend only a few dared to escape", whereas during the Age of Romanticism,

"Foreignizing translation began to be seen as a highly welcome possibility to help the reader to overcome the linguistic barrier, but at the same time without depriving him of 'the foreign' which usually emerges when contact is made with a different culture."3 (Bolaños, 2008, p.160).

At present, Shveitser (1988, p.176) postulates the existence of a general translation norm: "The modern norm of translation differentiates itself by its great severity, a clearer orientation towards recreation of the original which reflects the author's communicative intention." 4 I subscribe Shveitser's view and consider that modern literary translation would tend to be, as a rule, faithful to the original, i.e. the translator would attempt to recreate the communicative purpose of the original author. However this does not mean that a translator should use one single strategy throughout his task; in fact he usually adheres to one general translation norm, e.g. translate by keeping as much as possible the communicative purpose of the original author, which does not rule out the need to domesticate, fereignize, or adapt at some specific points of the translated text if and as required.

In the remainder of this paper, first I will make a brief presentation and contextualization of Cien años de soledad, then I will discuss the overall translation norms I could trace in the English, German,

3 „In der Epoche der belles infidèles, die im Mitte des 17. Jahrhunderts in Frankreich ihren ersten Höhepunkt hatte, herrschte das einbürgende Übersetzung als eine kulturelle Norm vor, der sich nur wenige zu entziehen wagten. [...] In der Zeit der Romantik [...] begann man im verfremdenden Übersetzen eine hochwillkommene Möglichkeit zu sehen, dem Leser über die Sprachbarriere hinwegzuhelfen, ohne ihm dabei gleichzeitig das 'Befremden' zu ersparen, das jede Begegnung mit einer der andersartigen Kultur auszulösen pflegt". (Albrecht 1998:76).

4 «Современная норма перевода отличается больщей строгостью, более четкой ориентацей на воспроизведение текста, выражаюшего коммуникативную интенцию автора». (Shveitser 1988:176).
French, Portuguese, and Russian texts. I will round up the text with some conclusions drawn from the previous discussion.

\section{Brief Presentation and Contextualization of the Novel}

According to Eligio García Márquez (2001, p.14), One Hundred Years of Solitude was first printed in Buenos Aires, Argentina, by the publishing house Sudamericana on May $30^{\text {th }}$ 1967. It was available in bookstores and newsstands on Monday July $5^{\text {th }}$ 19675. Some of the twenty 'chapters' or 'sections' of the novel -which are untitled and unnumbered in the original- had been previously published in different Latin American literary magazines and the Colombian newspaper El Espectator. The Peruvian magazine Amarú included chapter twelve where Remedios the Beauty began to rise; $E c o$, from Bogotá, published chapter seventeenth about the death of Úrsula, Rebeca and the twin brothers Aureliano Segundo and José Arcadio Segundo; also in Bogotá, the literary magazine Magazin Dominical of the newspaper El Espectador included the first chapter about Mequíades, alchemy and the discovery of ice; Diálogos, a Mexican magazine of art, literature and human sciences published chapter sixteen that narrates a rainy season that lasted 'four years, eleven months, and two days'; but the most important and only Latin American literary magazine of the time was Mundo Nuevo from Buenos Aires, which had already published exclusive interviews with the best Latin American writers and was considered the voice of the so-called Latin American literary boom. In an interview with Mexican writer Carlos Fuentes, already well-known at that time, he spoke of Gabriel García Márquez and his novel in these laudatory terms:

5 "Impresa por primera vez en forma de libro en mayo de 1967, en Buenos Aires, Argentina. Así reza en el colofón, página 352, de esta 'edición príncipe' de la editorial Sudamericana: 'se terminó de imprimir el treinta de mayo del año mil novecientos sesenta y siete en los talleres gráficos de la Compañía Impresora Argentina, Calle Alsina No. 2049, Buenos Aires'. Seis días después -el lunes 5 de junio de 1967, exactamente-, salió al mercado en las librerías y los quioscos de revistas y periódicos de la capital argentina" (Eligio García Márquez 2001, p.14). 
Look -said to Emir Rodríguez Monegal- I've just read the first 75 pages of One Hundred Years of Solitude, a work in progress by Colombian novelist Gabriel García Márquez. No doubt, it’s definitely a masterpiece. ${ }^{6}$

Even though García Márquez had previously published four books: Leaf Storm, No One Writes to the Colonel, Big Mama's Funeral, and In Evil Hour, he was not a well-known writer in Argentina (E. García Márquez, ibíd, p. 17). Thus, when Fuentes mentioned him and praised openly his novel in progress it helped a lot to locate García Márquez on the 'map' of the best Latin American writers together with Fuentes himself, Borges, Rulfo, Onetti, Cortázar, Carpentier and Vargas Llosa. When publisher Paco Porrúa from Sudamericana heard of García Márquez, he was an unknown writer to him until Luis Harss talked about him in Buenos Aires, information confirmed in Fuentes's interview. (ibíd, p. 59). In July 1964, Fuentes had written an essay on "The new Latin American Novel", published in La cultura en Mexico. He described there the features of a new novel which "demonstrated the death of bourgeois realism and the advent of a much more powerful literary reality", which was to characterize the Latin American Boom. ${ }^{7}$ He proudly announced: "Gentlemen, don't fool yourselves: the old [writers] are dead. Vargas Llosa, Cortázar, and Carpentier are alive" (ibíd, p. 586). And in the same essay he also mentioned as authors of this new Latin American novel Uruguayan Juan Carlos Onetti, Carlos Martínez Moreno, Chilean José Donoso, Argentinian Ernesto Sábato and Colombian Gabriel García Márquez (ibíd, p.589). Thus, clearly Carlos Fuentes played a crucial role in paving the way for García Márquez to join the Latin American Boom as one of

6 "Fíjate -le dijo Fuentes a Emir Rodríguez Monegal-, acabo de leer las primeras 75 cuartillas de Cien años de soledad, la work in progress del novelista colombiano Gabriel García Márquez. Son absolutamente magistrales". (Eligio García Márquez 2001, p.30).

7 Pym (2000, p.76) also perceives the Latin American Boom as a reaction against realism: "More profoundly, phenomena like the boom in Latin American literature in the 1960s and 1970s concerned many literatures as well as English, as translators and critics across Europe latched on to experimental fiction as an antidote to the dominant realism of the day." its protagonists, a literary movement which reacted against the prevailing aesthetic literary norm which favored realism.

Gabriel García Márquez had been struggling to find the tone to tell the story of the novel for about twenty years, until about 18 months before starting writing it he had some epiphany about how to do it:

One day, as we were heading to Acapulco with Mercedes and the kids, I was driving my Opel, thinking obsessively on One Hundred Years of Solitude when suddenly I had a revelation: I should tell the story precisely the way my grandmother used to tell hers, beginning with that afternoon when a kid is taken by his father to discover ice. ${ }^{8}$

A technical narrative problem García Márquez had at that time was how to deal with the novel's temporal structure. Until one day he found out what was wrong. Instead of insisting on keeping a rigid and realist temporal structure, he had to use time as freely as he used space:

Instead of racking my brains in following a strict chronological order I had to use a multidimensional time structure. Thus, if $\mathrm{A}$ had to be 20 years younger than the chronological order indicated then it would be 20 years younger. The same was valid for $\mathrm{B}, \mathrm{C}$ and all characters. When time was freed, the novel started flowing by itself. ${ }^{9}$

García Márquez' One Hundred Years of Solitude is considered a novel that best illustrates the 'realmagic' (Lo real maravilloso), a feature Cuban writer Alejo Carpentier assigned to the Latin American

8 “Un día, yendo para Acapulco con Mercedes y los niños, iba yo manejando mi Opel, pensando obsesivamente en Cien años de soledad, cuando de pronto tuve la revelación: debía contar la historia como mi abuela me contaba las suyas, partiendo de aquella tarde en que el niño es llevado por su padre a conocer el hielo". (E. García Márquez 2001, p.69).

9 "En vez de romperse la cabeza por seguir el hilo cronológico estricto debía usar un tiempo de varias dimensiones. Así, en un capítulo, si le convenía que $A$ tuviese veinte años menos de lo que indicaba la cronología, entonces $A$ debía tener veinte años menos. Lo mismo para $B$ y para $C$ y para todos. Cuando se liberó el tiempo, la novela empezó a fluir sola". (E. García-Márquez 2001, p.598). 
novel in the essay "Lo real maravilloso americano" which appeared as a preface to his 1949 novel El reino de este mundo (ibíd, p.591). According to Carpentier, Latin American reality is magic and the novelist's task is to show it (ibíd, p. 592). García Márquez' novels are anchored in the magic Latin America reality that surrounded him:

I was born and grew up in the Caribbean. I know it country by country and island by island, and maybe this is the origin of my frustration that it has not ever occurred to me or has it been more amazing than reality itself. The farthest I have reached is to transpose it with poetic resources but there is no one single line in my books which has not originated in a real fact" (García Márquez, 1980, p.156).10

García Márquez' (2002) autobiography Vivir para contarla is full of intertextual ${ }^{11}$ allusions, some explicit other implicit, to people, places, and actions he fictionalized in One Hundred Years of Solitude: for instance, his memory of his hometown Aracataca as "a good place to live, where everybody was an acquaintance, built on the bank of a river of clear water that ran along a bed of polished stones, which were white and enormous, like prehistoric eggs" 12 (ibíd, p.11; my emphasis on García Márquez’ own disguised quotation of One Hundred Years of Solitude); "It was there -my mother pointed out that

10 “Yo nací y crecí en el Caribe. Lo conozco de país por país, isla por isla, y tal vez de allí provenga mi frustración de que nunca se me ha ocurrido ni he podido hacer nada que sea más asombroso que la realidad. Lo más lejos que he podido llegar es a transponerla con recursos poéticos, pero no hay una sola línea en ninguno de mis libros que no tenga su origen en un hecho real". (García Márquez 1980, p.156)

11 Here I follow Genette's (1982) terminology: intertexts are defined as a relationship of co-presence between two or more texts, i.e. by the actual presence of one text in another; paratexts correspond to text title, subtitle, inter-title, prefaces, postscripts, etc.; marginal notes, footnotes, final notes; epigraphs, illustrations, jacket,etc.; metatexts refer to the commentaries or to what is generally considered the genre of literary criticism.

12 "Lo recordaba como era: un lugar bueno para vivir, donde se conocía todo el mundo, a la orilla de un río de aguas diáfanas que se precipitaban por un lecho de piedras pulidas, blancas y enormes como huevos prehistóricos". (G. García Márquez 2002, p.11). day- where the army had killed an uncertain number of banana workers in 1928"13 (ibíd, p.22).

The train stopped at a station without a town and sometime later it passed by the only banana farm on the road which had a sign written at the entrance: Macondo. That word had called my attention from the first trips I had made with my grandfather, but only as an adult did I find out that I liked its poetic resonance ${ }^{14}$ (ibíd, p.28).

One Hundred Years of Solitude was an immediate best-seller in Buenos Aires and the rest of Latin American capitals. In Buenos Aires, García Márquez is still the living author who sells most books and in the case of this novel there have been more than one hundred editions and more than two million books sold in Buenos Aires and the so-called Southern Cone: Argentina, Uruguay, Paraguay and Chile (ibíd, p.21). In Munday's (2001, p.194) words:

García Márquez has been extremely successful commercially, not only in his native Colombia, and throughout the Spanish-speaking countries, but also worldwide. Sales of his best-known One Hundred Years of Solitude continue to be strong, even in English, which is notoriously difficult market for foreign authors.

\section{The Translations and the Translators: Overall Translation Norms}

There have been many editions of the novel in Latin America and in Spain. In Colombia the copyright was initially granted to Editorial Oveja Negra and later on was transferred to Grupo Editorial Norma which presently publishes García Márquez’ work in Colombia as well as in Barcelona, Buenos Aires,

13 “Fue allí, según me preciso mi madre aquel día, donde el ejército había matado en 1928 un número nunca establecido de jornaleros del banano" (G. García Márquez 2002, p.22).

14 "El tren hizo una parada en una estación sin pueblo, y poco tiempo después pasó frente a la única finca bananera del camino que tenía el nombre escrito en el portal: Macondo. Esta palabra me había llamado la atención desde los primeros viajes, pero sólo de adulto descubrí que me gustaba su resonancia poética". (G. García Márquez 2002, p.28). 
Caracas, Guatemala, Lima, México, Panamá, Quito, San José, San Juan, San Salvador, Santiago de Chile and Santo Domingo. For this analysis I am using the 1984 edition published by Editorial Oveja Negra as part of the series Biblioteca de Literatura Colombiana.

On the other hand, as regards the translations of the novel, Carmen Balcells, who has been García Márquez representative for publishing matters, managed to ensure that One Hundred Years of Solitude would be translated into the main world languages.

Feltrinelli was the second foreign publishing house to sign a contract for translating One Hundred Years of Solitude in October 1967, after the French Seuil had signed up, whereas in November Harper and Row (which had paid one thousand dollars for the author's four previous books) attained the copyright for the American market. There was only an editorial inconvenience with the novel in Germany where it had been refused initially by four publishing houses: Rowolht, Sigher, Hausser and Aufbau. Only Kiepenheur (sic) signed up a contract in November 1968, when the book's success was well-known in France and Italy ${ }^{15}$ (Saldívar 1997, p.458).

According to Zuluaga (2005, p.95), "One Hundred Years of Solitude has sold more than thirty million copies in about the forty languages into which it has been translated." 16 However, on the back cover of the German translation, one reads that since its appearance it has sold more than 400

15 "La verdad es que Feltrinelli fue la segunda editorial extranjera en contratar Cien años de soledad, en octubre de 1967, después de la francesa Seuil, que la contrató en abril, mientras en noviembre Harper and Row (que había comprado por mil dólares los cuatro libros anteriores del autor) se hacía con los derechos para el mercado norteamericano. El único tropiezo editorial que tuvo la novela fue en Alemania, donde inicialmente la rechazaron cuatro editoriales: Rowohlt, Sigher, Hausser y Aufbau. Sólo Kiepenheur la contrató en noviembre de 1968, cuando ya el escándalo del libro había estallado en Francia e Italia". (Saldívar 1997, p.458).

16 "En los mentideros editoriales se calcula que de Cien años de soledad se han vendido más de treinta millones de ejemplares en los cerca de cuarenta idiomas a los que se encuentra traducida". (Zuluaga 2005, p.93). million copies ${ }^{17}$ i.e. ten times more than Zuluaga's estimation. It was because of the translations of his works, but especially of One Hundred Years of Solitude that García Márquez became a worldwide known writer to the extent that he was awarded the Nobel Prize for Literature in 1982.

\section{English Translation}

It is copyrighted in 1970 by Harper \& Row publishers. The translator hired for the job was Gregory Rabassa who had not previously translated García Márquez' works. No One Writes to the Colonel and other Stories had been translated by J. S. Berstein in 1968. The text of One Hundred Years of Solitude I used for the analysis is the First Perennial Classics edition published in 1998. On the cover no mention is made of Gregory Rabassa. At the bottom of the third page, in rather small letters, it reads: Translated from the Spanish by Gregory Rabassa. On the fourth page there is the copyright information; and next to it, on the sixth page, a dedication: for jomi garcía ascot and maría luisa elío. They were close friends of García Márquez and, according to his brother Eligio,

They provided moral and physical support: they would go the market and buy a whole stock of supplies for them, they would all cook and drink whiskey, for as long as there was whiskey there was no misery, as García Márquez used to say later on (E. García Márquez 2001, p.613).

Then, on the next page is a family tree (a paratext) which does not appear in the original. The text of the novel finishes on page 448. On pages 449-453 there appears a biography of García Márquez (a paratext). On pages $455-458$ there is a commentary (a metatext) on One Hundred Years of Solitude. On the reverse of the back cover there is a list of García Márquez books with commentaries (metatexts) from diverse sources: New York Times Book Reviews, New

17 „Hundert Jahre Einsamkeit ist Gabriel García Márquez’ berühmtester Roman, der seit seinem Erscheinen eine Weltauflage von über 400 Millionen Exemplaren hat und zu den großen Romanen des 20. Jahrhunderts gehört". 
Republic, Newsweek, Library Journal, and Publishers Weekly. The back cover is split into two columns. On the left there appear two laudatory comments, one by William Kennedy from New York Times Book Review: "One Hundred Years of Solitude is the first piece of literature since the book of Genesis that should be required reading for the entire human race", and another by Paul West from Book World: "Fecund, savage, irresistible... In all their loves, madness and wars, their alliances, compromises, dreams and deaths... The characters rear up large and rippling with life against the green pressure of nature itself." On the right column it reads one hundred years of solitude. Translated by Gregory Rabassa. There is a photograph of García Márquez, below of which there is a list of his main books and mention is made that he "was awarded the Nobel Prize for Literature in 1982".

All paratexts and metatexts included in the translation seem to have a clear commercial purpose. They help to sell the book by convincing potential buyers of the literary quality of the book. In the English editions there is something which calls for particular attention: the inclusion of a family-tree which does not appear in the original. In Rabassa's 2005 book If This Be Treason. Translation and Its Dyscontents. A Memoir, where he writes about his long translation experience with works of the best known Latin American and Brazilian authors, he comments on the episode of the family tree:

The editors added a family tree which they had me concoct for the translation and at the same time I thought it a good idea, something to help readers keep all the characters straight and to let them see the complex interrelationships. Later on, after the book had come out, I had second thoughts. If García Márquez had wanted such a table he would have put one in the first Spanish edition. I came to think that perhaps confusion (and fusion) was meant to be part of the novel, showing how all members of our species look to apes or horses, who would have trouble distinguishing among yahoos. (ibíd, p. 100).
Thus, there was an initial agreement between the initiator's translation instruction about including a family tree and the translator's view, even though later on Rabassa had second thoughts about it. Interestingly enough, Rabassa tells us about the inclusion of this family tree in a Spanish edition: "It's puzzling, or is it, since it was put together by academics, that the fine footnoted Spanish edition in the Cátedra series also carries a genealogical table at the beginning" (ibíd). This could be a case of a phenomenon we could call back intertextuality.

In an interview with Font Castro, García Márquez acknowledges that he actually thought about including a family tree: "Yes I did (drew a family tree). But a family tree is easier than it seems to be..."18 (E. García Márquez 2001, p. 611). And, in another interview, this time with Elena Poniatowska, he clarified the fate of the family tree: "I even drew a family tree but I tore it up"19 (ibíd, p. 619). Thus, Rabassa is right, García Márquez did not want a family tree included in the novel, and therefore he discarded this idea. The editor's inclusion of a family tree, Rabassa tells us, would be 'something to help readers keep all the characters straight', but that was not García Márquez intent, or else he would have included his own version of the family tree. What is clear here is that the English editors of the novel had a patronizing attitude towards the TL readership. By including the tree they would impose a certain reading of the novel which would 'make it easier' to comprehend who the different characters were, thereby avoiding the possibility of getting confused.

\section{German Translation}

It is copyrighted in 1970 by Verlag Kiepenheuer \& Witsch. I am using in this analysis the 2001 edition. The novel was translated by Curt Meyer-Clason who, besides having his own works, has also translated some of the most important Latin American, Spanish and Brazilian authors such as Jorge Luis Borges,

18 "Sí, lo hice (el árbol genealógico). Pero resulta que el árbol genealógico es más fácil de lo que parece..." (E. García Márquez 2001, p.611).

19 "Incluso hice un árbol genealógico, pero lo rompí". (E. García Márquez 2001, p.619). 
Jorge Amado, Rafael Alberti, Rubén Darío, Pablo Neruda, Vladimir Nabokov, João Guimarães Rosa, César Vallejo and most of Gabriel García Márquez' works. His extraordinarily extensive and highquality translation activity can be likened to that of Gregory Rabassa in the English speaking world. However, unlike Rabassa, unfortunately he has not written about his translation work. On the cover one reads, besides Gabriel García Márquez and the title in German Hundert Jahre Einsamkeit, that the text type or genre 'novel' is explicitly mentioned: Roman. This additional information which is not in the original is aimed at helping potential readers, not well-acquainted with Latin American literature, to identify the book's genre. On the first page some information on the book (Über das Buch) and on García Márquez (Der Autor) has been included. On the third page there appears again the author's name and the book's title, followed by the word 'novel' (Roman) and by the translator's name: Aus dem Spanischen von Curt Meyer-Clason. On page 5 there is the dedication we also saw on the original and on English edition: For Jomi García Ascot and María Luisa Elío (Für Jomi García Ascot und María Luisa Elío). On page 7 the text of the novel begins. The novel finishes on page 468 . On pages 471,473 , 475,477 , and 479, some of the best books of García Márquez, a book on each page, is presented with a brief commentary (metatext) by authors of some of the most prestigious, or best known for that matter, German magazines and newspapers: Die Zeit, Frankfurter Allgemeine Zeitung, and Der Spiegel. On the back cover it reads that One Hundred Years of Solitude has sold over 400 million copies worldwide and belongs to the great novels of the $20^{\text {th }}$ century. Just like in the English translation, there is an extremely laudatory commentary by Jochen Hieber from Frankfurter Allgemeine Zeitung: "Without the rich books by Gabriel García Márquez our world would be definitely poorer." 20

20 “Ohne die reichen Bücher von Gabriel García Márquez wäre unsere Welt entschieden ärmer". (Jochen Hieber, Frankfurter Allgemeine Zeitung.

\section{French Translation}

It is copyrighted in 1968 by Éditions du Seuil. It was the first translation of the novel into a foreign language. I am using the 1995 edition in this analysis. The novel was translated by Claude and Carmen Durand. On the book cover it reads Gabriel García Márquez. Cent Ans de Solitude. On the third page the names of the author and the novel are included. Just like in the German translation, in the French translation the word 'novel' has been added above the name of the translators with an additional remark on the Spanish from Colombia: Gabriel García Márquez. Cent Ans de Solitude. Roman. Traduit de l'espagnol (Colombie) par Claude et Carmen Durand. However, unlike in the German translation, the word 'novel' does not appear on the cover, but on the back cover of the French translation. This means that it is implied that French readers may be somehow acquainted with the name of García Márquez, and in case this is not so, then the text type or genre marker 'novel' can be read on this third page or on the back cover. On pages I-VII there is a literary commentary by author and translator Albert Bensoussan. It finishes with a brief biographical note on García Márquez and, like the English translation, with information on the Nobel Prize: "He attained the Nobel Prize for Literature in 1982." ${ }^{21}$ On page 7 there is a dedication, but this time it is for Carmen and Álvaro Mutis. Colombian writer Álvaro Mutis and his wife Carmen were also close friends of García Márquez in Mexico by the time he was writing the novel. The text of the novel begins on page 9 and finishes on page 437. On pages 438-439 there is a list of other works by García Márquez. On pages 443-453 there is a list of books which appeared in the Collection Points. On the back cover, as said above, the word 'novel' has been included, followed by the names of the author and the novel and information that the text was translated by Claude and Carmen Durand.

There are three footnotes included in the text. The first one, at the end of chapter 6, refers to the last name of captain Roque Carnicero ('butcher'): "El jefe del pelotón, especialista en ejecuciones

21 "Il a reçu le prix Nobel de littérature en 1982". 
sumarias, tenía un nombre que era mucho más que una casualidad: Roque Carnicero" (p.106) (my emphasis). As the captain's last name 'Carnicero' was not translated and its meaning is not transparent in French, an explanatory footnote was added (carnicero: boucher): "Le chef du détachement, specialisé dans des exécutions sommaires, portait un nom qui était bien plus qu'un simple hasard: capitaine Roque Carnicero" (p.131) (my emphasis). Rabassa solved this problem by adding an explanation directly in the English text: "The leader of the squad, a specialist in summary executions, had a name that had much more about than chance: Captain Roque Carnicero, which meant butcher" (p.130) (my emphasis). Meyer-Clason solved the problem in the German translation by translating the captain's last name into its German equivalent: "Der auf Blitzerschießungen spezialisierte Chef des Kommandos hatte einen Namen, der nicht zufällig war: er hieß Hauptmann Roque Fleischer" (p.140) (my emphasis). A similar solution was also provided by the Russian translators by translating into Russian the captain's last name 'butcher': «Командовать расстрелом назначили капитана, которого отнюдь не случайно звали Роке Мясник - он был специалистом по массовым казням» (р.130) (my emphasis). The Portuguese translator had no inconvenience in leaving the captain's last name in Spanish as it is phonetically and graphemically very close to the Portuguese word for 'butcher' ('carniceiro'): "O chefe do pelotão, especialista em execuções sumárias, tinha um nome que era muito mais do que uma coincidência: Capitão Roque Carnicero" (p.118) (my emphasis).

The next footnote appears in chapter 8 and refers to Father Coronel's nickname: "El padre Nicanor, consumido por las fiebres hepáticas, fue reemplazado por el padre Coronel, a quien llamaban $E l$ Cachorro, veterano de la primera Guerra federalista" (p.127) (oginial's emphasis). The nickname was left untranslated in the French text: "Le père Nicanor, consumé par les fièvres hépatiques, fut remplacé par le Père Coronel, qu'on appelé el cachorro, vétéran de la première guerre fédéraliste" (p.158). The footnote reads: "Petit d'une bête fauve" ("Puppy of a wild beast"). Rabassa translated the nickname into English: "Father Nicanor, consumed by hepatic fever, was replaced by Father Coronel, whom they called "The Pup", a veteran of the first federalist war" (p.161). Meyer-Clason left the nickname in Spanish but added a hyphenated explanation: "Der von Leberfieber verzehrte Pater Nicanor wurde durch Pater Coronel mit dem Beinamen El Cachorro -junger Hund-, Veteran des ersten Föderalistenkrieges, abgelöst" (p.171) (original's emphasis). Butririna and Stolbov, the Russians translators, decided to change Father Coronel's nickname from 'puppy' ('щенок') to 'grumpy' ('ворчун'): «Вконец изнуренный приступами болезни печени, падре Никанор был заменен падре Коронелем, ветераном первой войны, в Макондо его прозвали Ворчуном» (p.158) (my emphasis). Eliane Zagury included a long fotnote in the Portuguese translation to attempt to explain the use of this last name as a type of religious-related 'cultural caricature' by García Márquez. Interestingly enough, she did not simply translate the nickname into Portuguese ('cachorro'), but added a diminutive form not present in the original: "O Padre Nicanor, consumido pelas febres hepáticas, foi substituído pelo Padre Coronel, a quem chamavam $O$ Cachorrinho, veterano da primeira guerra federalista" (p.144) (original's emphasis).

The third footnote also appears in chapter 8 . It has to do with an allusion presented in the original to a work by Spanish writer Zorrilla El puñal del godo without mentioning it explicitly: "Se fue al teatro, donde una compañía española anunciaba El puñal del zorro, que en realidad era la obra de Zorrilla con el nombre cambiado por orden del capitán Aquiles Ricardo, porque los liberales les llamaban godos a los conservadores" (p.132) (original's emphasis). If the reader does not know the actual name of Zorrilla's work, there is confusion in understanding the passage. Claude and Carmen Durand seem to have been aware of this difficulty and decided to add the actual name of Zorrilla's play to make explicit the allusion: "Il se rendit au théâtre où une troupe espagnole affichait el Puñal del Zorro qui, en réalité, était l'œuvre de Zorrilla, el Puñal del Godo, mais son nom avait été changé sur ordre du capitaine Aquiles 
Ricardo, parce que les libéraux traitaient les conservateurs de godos" (p.165) (original's emphasis). The footnote clarifies the pejorative connotation of the word godos, which was kept in the original Spanish form to facilitate the direct link to Zorrilla's work. Rabassa keeps the diffuse allusion in English in the same way as it appears in the original: "He went to the theater, where a Spanish company was putting on The Dagger of the Fox, which was really Zorrilla's play with the title changed by order of Captain Aquiles Ricardo, because the liberals called the conservatives Goths" (p.167). Meyer-Clason used the same strategy as the French translators and added the actual name of Zorrilla's play to facilitate the comprehension by German readers: "Er ging ins Theater, wo eine spanische Kompagnie 'Der Dolch des Zorro' spielte, ein Stück, das in Wirklichkeit Zorillas 'Der Dolch der Goten' war; doch der Name war auf Befehl des Hauptmanns Achilles Ricardo verändert worden, da die Liberalen die Konservativen Goten nannten" (p.179) (original's emphasis). Butririna and Stolbov kept the original allusion and did not add the actual name of Zorilla's play in their Russian translation: «И отправился в театр, где испанская труппа играла пьесу 'Кинжал Сорро' - на самом деле это была трагедия Соррильи, но название ее изменили по приказу капитана Акилеса Рикардо, потому что 'готами' либерали называли консерваторов» (p.166). Eliane Zagury included a footnote in her Portuguese translation, but she does not clarify that the allusion refers specifically to Zorilla's play El puñal del godo because she also mentions another play by Zorrilla, Don Juan Tenorio. She kept the allusion in the same way it is presented in the original: "Foi ao teatro, onde uma companhia espanhola anunciava O Punhal do Zorro, que na realidade era a obra de Zorrilla com o nome trocado por ordem do Capitão Aquiles Ricardo, porque os liberais chamavam de godos os conservadores" (p.151) (original's emphasis).

\section{Portuguese Translation}

It is copyrighted in 1969 by Distribuidora Record de Serviços de Impresa S. A. I am using in this analysis the $199440^{\text {th }}$ edition. It was translated by
Eliane Zagury. On the cover it reads Prêmio Nobel de Literatura. Gabriel García Máquez. Cem anos de solidão, 40a Edição. On the second page there is a brief biography of García Márquez, but under the title of the novel's name Cem anos de solidão. On the third page there appears a list of works by the author (Obras do autor). On the fourth page there is a presentation page with the name of the author, below of which it reads Prêmio Nobel de Literatura (Nobel Prize for Literature); and then there appears the novel's title and information that it was translated by Eliane Zagury (Tradução de Eliane Zagury); below it reads: Teachers' Library National Program. MEC-FAE-1994. Free distribution (Programa Nacional Biblioteca do Professor. MEC-FAE-1994. Distribução Gratuita). The copyright information appears on page 5. On page 6 there is the original's dedication (Para Comí García Ascot e María Luisa Elío). The novel begins on page 7 and finishes on page 394. On the back cover there appears a large photograph of García Márquez.

Thirteen footnotes (paratexts) have been added to the Portuguese text. Six of them are identified as translator's notes (N.T.) which are aimed at providing readers with explanatory information the translator thought they required: the meaning of Father Coronel's nickname 'El Cachorro' (p.144); the identification of Spanish writer José Zorilla (p.151); the meaning of Colombian dances 'cumbiamba' (p.245), which Zagury calqued in an abbreviated form as 'cumbia'. Rabassa also left the original term untranslated in English but italicized it: 'cumbiamba' (p.273); Meyer-Clason changed the original meaning and activated a connotation related to drinking, not present in the original: 'Stegreifsauferei'; Claude and Carmen Durand reproduced the original's meaning but without using the Spanish word: 'bamboche'; Butririna and Stolbov transliterated the original into Cyrillic characters: 'кумбиамбе' and the term is explained in the book's glossary. Zagury also included a footnote in the Portuguese translation to explain the original metaphor 'el fragante y agusanado guayabal del amor' (p.231) which she translated as 'o fragante e bichado goiabal de amor' (p.265); Rabassa maintained the original metaphor in En- 
glish: 'the fragrant and wormy guava grove of love' (p.298); Meyer-Clason maintained the metaphor but used the general term 'fruit' instead of 'guava': 'der duftende, wurmstichige Obstgarten' (p.314); Claude et Carmen Durand did not reproduce the key word 'guayabal' of the original metaphor: 'chagrin d'amour parfumé et véreux' (p.292). Butririna and Stolbov modified the metaphor to include flower-related love instead of the original guava-related love: 'благоуханний и изъеденний червами цзвиник любви' (p.293) (my emphasis). Zagury also left untranslated the original term 'pamiamento' and added an explanatory footnote copied directly from Diccionario de Términos Filológicos by Fernando Lázaro Carreter (p.364). Rabassa left the original term 'Papiamento' (p.413). In Meyer-Clason German translation the language variety 'Papiamento' became 'gibberish': 'Kauderwelsch' (p.432); Claude and Carmen Durant also transformed 'papiamento' into a 'West Indian jargon': 'jargon antillais' (p.404). Butririna and Stolbov also transformed 'papiamento' into 'jargon': 'жаргоне' (p.404). Finally, in a footnote Zagury explains her understanding of the original's metaphor 'garrapatitas moradas' (p.335) and translated it as 'garranchinhos roxos' (p.381). It was translated into English as 'purple scribbling' (p.432), into German as 'Maulbeerfarbenem Gekleckse' (p.451), into French as 'gribouillis violets' (p.422), and into Russian as 'фиолетовыми каракулями' (р.422).

The remaining seven footnotes correspond to terms the translator seems not to have understood at first and thus it is explicitly marked that she got in touch with García Márquez and he clarified the meanings to her: "Explicação do autor à tradutora" ("Author's explanation to the translator"). The collaboration between author and translator is a very important aspect because in all the translations I analyzed this is the only case where direct contact with García Márquez was established by a translator. Even Rabassa did not get in touch with García Márquez. Zagury asked for clarification about the metaphor 'manos de gorrión' (p.7), translated as 'mãos de pardal' (p.8); she left untranslated the Spanish original 'niños-en-cruz' (p.90) and clarified its meaning in a footnote; she wanted to find out the meanings of 'legítimo perjudicador' (p.271), calqued as 'legítimo perjudicador' (p.308); 'angeles de diciembre' (p.315), also calqued as 'anjos de dezembro' (p.356); 'machucante de planta' (p.323), which was left untranslated (p.366); 'improperios cartaginenses' (p.334), calqued into Portuguese as 'impropérios cartagineses' (p.379), and 'camisa de inválido' (p.335), which was also calqued as 'camisa de inválido’.

\section{Russian Translation}

It is copyrighted in 1970. The novel was translated by N. Butirina and V. Stolbov. There are other two translations, one by T. Korobkina in 1982 and another by Pravosudov in 1999. The translation I used for this analysis is the first translation, 1997/2001 edition, by Butirina and Stolbov. On the first page it reads Symposium in Latin characters. On the second page there appears the trademark ex libris ${ }^{\oplus}$ and the name of the publishing house Symposium, the city (Saint Petersburg) and the year (2001), but this time in Cyrillic characters (CuMпозиум. Санкт-Петербург 2001). On the third page it reads Сто лет одиночества. Габриэль Гарсиа Маркес. -And in a very large type- Гарсиа Маркес (One Hundred Years of Solitude. Gabriel García Márquez. García Márquez). On the fourth page it reads that the edition was prepared and commented by Victor Andreev, and the artist was Michael Zan'ko. On the fifth page the name of García Márquez appears again. On the seventh page the name of the novel appears and below it, as in the German and French editions, the name of the genre 'novel' (Роман). The text of the novel begins on page 7 and finishes on page 438. An Appendix (Приложение) has been added on pages 439-482. In the first part of the Appendix a "Dialogue on the Novel in Latin America" between Gabriel García Márquez and Mario Vargas Llosa is reproduced. In the second part of the Appendix four brief texts García Márquez had written in 1950 for the newspaper $E l$ Heraldo appear: «Дочь полковника» [The Colonel's Daughter], «Сын полковника» [The Colonel's Son], «Возвращение Меме» [Meme's Transformation], and «Дом семьи Буэндиа» [The House of the Buendia 
Family] are collected under the heading of «Haброски к роману» [Sketches for a Novel]. Then the section Примечания (Notes) appears on pages 483504 . The notes contain a brief literary commentary on the novel (483-489), immediately followed by a glossary of 138 entries about the terms of the novel rooted in the Latin American culture (e.g. Macondo, yuca, ñame, auyama), and others which belong to a specialized field of knowledge (e.g. real, doubloon, astrolabe, compass, sextant, etc). The glossary is further expanded to include difficult terms on the "Dialogue on the Novel in Latin America" between Gabriel García Márquez and Mario Vargas Llosa and finishes with a brief note on Sketches for a Novel. There are no asterisks or other marks in the text of the novel which indicate that a word has been included in the glossary, so it is up to the reader to consult the glossary as he sees fit. A Table of Contents of the edition appears on page 505. On pages 506-512 there are commercial ads on other books by the publishing house "Symposium."

There are four footnotes in the Russian translation. The first two appear in chapter 5 and refer to the use of Latin sentences in the novel. The original Spanish reads:

-Hoc est simplicissimum -dijo José Arcadio Buendía-: homo iste statum quartum materiae invenit. El padre Nicanor levantó la mano y las cuatro patas de la silla se posaron en tierra al mismo tiempo.

-Nego -dijo-. Factum hoc existentiam Dei probat sine dubio (p.76), (original's emphasis).

The Russian notes include the translation of the Latin sentences: «Это очень просто. Этот человек открыл четвертое состаяние материи» (лат.) ["This is very simple. This man has discovered the fourth state of matter" (lat.)] and «Отрицаю. Этот факт неопровержимо доказывает бытие Божие» (ram.) ["I disagree. This fact irrefutably proves the existence of God" (lat.)], (p.92). The English (p.91), German (p.100), French (p.93), and Portuguese (p.84) translations have not translated the Latin sentences. This may indicate that the translators and editors of these translations presupposed more familiarity with the Latin language on the part of the TL readers than in the case of the average Russian readers.

Likewise, in the third footnote lack of familiarity with the English language is also presupposed. In chapter 18 the original reads:

Fue él quien le indicó que en el callejón que terminaba en el río, y donde en los tiempos de la compañía bananera se adivinaba el porvenir y se interpretaban los sueños, un sabio catalán tenía una tienda de libros donde había un Sanskrit Primer que sería devorado por las polillas seis años después si él no se apresuraba a comprarlo (p.298), (original's emphasis).

The Russian translation reproduces the original English term Sanskrit Primer and explains it in a footnote: «Учебник санскритского языка» (англ.), [“Textbook of the Sanskrit language” (ing.)], (p.374). Rabassa reproduces the original term in the English translation (p.384), and does not indicate, e.g. by using italics that it was in English in the original Spanish. Meyer-Clason maintained the original English term in inverted commas: 'Sanskrit Primer' (p.401). Claude and Carmen Durand in the French translation (p.375) as well as Eliane Zugary in the Portuguese translation (p.340) have also kept the original English in italics: Sanskrit Primer.

The fourth footnote also has to do with a foreign term in the original, this time a Catalan curse in the chapter 20: "Collons -maldecía-. Me cago en el canon 27 del sínodo de Londres" (p.334). Butririna and Stolbov kept the original Catalan term 'Collons' and explained it in a footnote: «Каталонское ругательство» [“Catalan curse”], (p.421). Rabassa kept the original in inverted commas and italics: " "Collons," he would curse" (p.431). Meyer-Clason translated the curse into German: "Hodenhunde"” fluchte er" (p.450). Claude and Carmen Durand kept the original Catalan term, italicized it and used an exclamation point: "Collons! Jurait-il" (p.421). Eliane Zagury also left the original Catalan word and italicized it: "-Collons - maldizia" (p.379). 


\section{Conclusions}

Regarding the initial socio-cultural translation norms that applied to the English, German, French, Portuguese, and Russian translations of Cien años de soledad, we can say that an aesthetic literary norm seems to have been at work when these novel's translations were published: a strong reaction against the so-called realist novel (Pym 2000). Thus, works by such Latin American authors of the literary 'boom' as Alejo Carpentier, Mario Vargas Llosa, Carlos Fuentes, Juan Rulfo, Julio Cortázar, and Gabriel García Márquez were welcomed and accepted as a renewing and invigorating force, not only of Latin American narrative but also of world literature. It is clear that this worldwide expansion of the Latin American novel would have not been possible without the crucial role played by these translations. But for its translations, García Márquez real-magic world portrayed in One Hundred Years of Solitude would have been confined only to the Spanish speaking community. In other words, the target languages aesthetic literary norms had room for the translations of the novel and they were initially accepted on the periphery of the corresponding literary polysystems, to use Even-Zohar's (1978/2000) terms, as attested by the market success of the novel (Munday 2001).

Besides, only in the English translation was there a translation norm that allowed for direct influence of the instructions of the translation initiator (or client) on the translated text in the form of adding a paratext, a family tree that was not in the original. As Rabassa tells us, he agreed with the editor's addition and only after the novel had been published did he have second thoughts. As shown above, García Márquez did not include the family tree, so the editor's addition can be regarded as a direct intervention in the translated text. The fact that the other translations did not include the additional family tree indicates that a translation norm was applied according to which the original was perceived as somehow sacred so that there was no room for alterations in the translated texts. In the English translation this sacred character of the original was overridden by an alleged enhancement of textual comprehension on behalf of the potential readers.
Another interesting aspect with respect to the valid translation norms when the translations were initially published has to do with the fact that the translators' names did not appear on the novels' covers. This indicates that they were not considered at the same level of the novel's author. Venuti's (1995) hypothesis about the translators' invisibility in modern Translation Studies is clearly illustrated here. Translators are not considered authors but simply re-creators.

With regard to the translation norm related to the text type or genre it is important to point out that the German, French, and Russian translations explicitly identify the text type as a 'novel'. This would indicate that there is a translation norm at work, according to which translations' publishers can help TL readers to clearly identify what type of text they are dealing with. This could be a patronizing attitude towards the target language readers in as much as they are regarded as 'ignorant' of the literary production beyond their own borders. It is really hard to think that the novel's title is not telling enough about the nature of the text type involved.

Another textual translation norm is related to the fact that footnotes are considered a valid resource (a paratext) that can be added to the translations in case it is deemed necessary. The translations analyzed have shown that there is a continuum from no footnotes (English and German), to some (French and Russian) or to many (Portuguese). Furthermore, there seems to be another translation norm at work in the use of footnotes, according to which a domesticating or a foreignizing translation strategy is implemented. When footnotes are included it is possible to use either a foreignizing strategy where the original term may be kept in the translation (e.g. 'Carnicero' in French) but its meaning explained in a footnote, or a foreignizing strategy with an explanation added, not in a footnote, but directly in the translated text (e.g. 'Carnicero, which meant butcher' in English). It is also possible to use a domesticating strategy where the foreign item is directly translated into the target language (e.g. 'Roque Fleischer' in German, or 'Роке Мясник' in Russian), where the meaning is kept but a new effect, not intended by 
the original's author, is created on the target reader which affects credibility, i.e. it is not very likely that precisely a 'bad' character bears a German or a Russian last name in the original Spanish novel. All in all, one can say that when there are no footnotes in the translation a tendency can be traced towards the use of a domesticating strategy that helps TL readers to 'grasp' immediately the meaning of the original; however the price paid for this device is that the original novel's credibility in depicting its characters can be affected negatively. Using Koller's (2000) description of the double-binding relationship in translation equivalence, we can say that, in translating names, García Márquez’s translators, as seen above, had to make a difficult choice -and they actually did- between faithfulness to the original (foreignizing strategy but with inclusion of

\section{Bibliografía}

Albrecht, J. (1998). Literarische Übersetzung. GeschichteTheorie-Kulturelle Wirkung. Darmstadt: Wissenschaftliche Buchgesellschaft.

Bolaños, S. (2008). Towards an integrated translation approach. A dynamic translation model (DTM). Ph D., Dissertation, University of Hamburg. Obtenido desde [http//www.sub.uni-hamburg.de/opus/ volltexte/2008/3726].

Bolaños, S. (1998). "Crítica de la traducción al alemán de El coronel no tiene quien le escriba". En: Cien años de soledad treinta años después. XX Congreso Nacional de Literatura, Lingüística y Semiótica. Bogotá: Universidad Nacional de Colombia y Instituto Caro y Cuervo, pp. 167-196.

Even-Zohar, I. (1978/2000). “The position of translated literature within the literary polysystem”. En: L. Venuti (ed.), (2000). The translation studies reader. London y New York: Routledge, pp. 192-197.

García Márquez, G. (2002). Vivir para contarla. Bogotá: Grupo Editorial Norma.

García Márquez, E. (2001). Tras las claves de Melquíades. Historia de Cien años de soledad. Bogotá: Grupo Editorial Norma. footnotes) or to the TL community (domesticating strategy with a possible weakening of credibility of the characters depicted in the original). However, as discussed above, this is one punctual translation strategy which concerned only the translation of names or expressions in a foreign language in the original novel.

Finally, I can say that the overall prevailing translation norm in all the analyzed translated texts is faithfulness to the original author's communicative purpose. This means that the translators did not alter the textual sequence of the contents of the original and stuck to the closest equivalent expression in the target language. When punctual transformations, adaptations and additions were called for, they were carried out by using diverse translation strategies such as domesticating or foreignizing.

García Márquez, G. (1984). Cien años de soledad. $1^{\mathrm{a}}$ edición. En: Biblioteca de Literatura Colombiana. Bogotá: Editorial Oveja Negra.

García Márquez, G. (1980). Notas de prensa. El Espectador. En: Gabriel García Márquez (1997). Vida y Obra. Bogotá: Grupo Editorial Norma.

García Márquez, G. (1970/2001). Hundert Jahre Einsamkeit. Traducción de Curt Meyer-Clason. Köln: Kiepenheur \& Witsch.

García Márquez, G. (1970/1998). One hundred years of solitude. Translated by Gregory Rabassa. New York: First Perennial Classics edition.

García Márquez, G. (1970/1997/2001). Cто лет одuночества. Traducción de N. Butririna \& V. Stolbov. Saint Petersburg: Symposium.

García Márquez, G. (1969/1994). Cem anos de solidão. Traducción de Eliane Zagury. 40 ${ }^{\text {th }}$ edition. Rio de Janeiro: Editora Record.

García Márquez, G. (1968/1995). Cent Ans de Solitude. Traducción de Claude \& Carmen Durant. Paris: Éditions du Seuil.

Genette, G. (1982). Palimsestes. La littérature au second degré. Paris: Editions du Seuil. 
Hermans, T. (2000). "Norms of Translation". En: P. France (ed.), (2000). The Oxford Guide to Literature in English Translation, pp. 10-15. Oxford: Oxford University Press.

Koller, W. (2000). “Der Begriff der Äquivalenz in der Übersetzungswissenschaft”. En: C. Fabricius-Hansen \& J. Ostbo (eds). Übertragung, Annährung, Angleichung. Sieben Beiträge zu Theorie und Praxis des Übersetzens, pp. 11-29. Frankfurt am Main: Peter Lang.

Luis, W. \& Rodríguez-Luis, J. (eds.), (1991). Translating Latin America. Culture as Text, pp. 35-44. New York: State University of New York at Binghamton.

Martin, G. (2009). Gabriel García Márquez. A Life. New York: Alfred A. Knopf.

Munday, J. (2001). Introducing Translation Studies. Theories and Applications. London/NewYork: Routledge.

Pym, A. (2000). "Late victorian to the present". En: P. France (ed.), (2000). The Oxford Guide to Literature in English Translation. Oxford: Oxford University Press, pp. 73-81.

Rabassa, G. (2005). If this be treason. Translation and its dyscontents. A Memoir. New York: A New Directions Book.

Rabassa, G. (1991). "Words Cannot Express ... The Translation of Cultures”. En: W. Luis \& J. Rodríguez-Luis (eds.). Translating Latin America. Culture as Text, pp. 35-44. New York: State University of New York at Binghamton.
Rabassa, G. (1989). "No two snowflakes are alike: translator as metaphor”. En: J. Biguenet \& R. Schulte (eds.). The Craft of Translation, pp. 1-12. Chicago \& London: The University of Chicago Press.

Rabassa, G. (1971/1987). “The ear in translation”. En: The world of translation. With an introduction by Gregory Rabassa, pp. 81-85. New York: PEN American Center.

Rabassa, G. (1971/1987). "Preface for the third printing". En: The world of translation. With an introduction by Gregory Rabassa, pp. ix-x. New York: PEN American Center.

Robinson, D. (2000). “The limits of translation”. En: P. France (ed.), (2000). The Oxford Guide to Literature in English Translation, pp. 15-20. Oxford: Oxford University Press.

Saldívar, D. (1997). García Márquez. El viaje a la semilla. La biografía. Bogotá: Ediciones Santillana S.A.

Shveitser, A. D. (1988). Теория перевода. Статус, проблемы, аспекты. Москва: Наука.

Toury, G. (1995). Descriptive translation studies and beyond. Amsterdam \& Philadelphia: Benjamins.

Venuti, L. (1995). The translator's invisibility: a history of translation. London \& New York: Routledge.

Zuluaga, C. (2005). Gabriel García Márquez. El vicio incurable de contar. Bogotá: Panamericana Editorial Ltda. 